\title{
An Assessment Related To Instructors Views about Teachers Eligibility and Teacher Candidates' Selection Process
}

\author{
Ayşe Nur KUTLUCA CANBULAT
}

\author{
Summary
}

\section{INTRODUCTION}

Teaching is a profession has too much duties and responsibilities compared to other professions. Because teachers give direction to the future through their trained individuals. Therefore, the roles and responsibilities of this profession to fulfill in the best way are expected from individuals who will assume this profession. Teaching profession requires how to teach as the students understands besides knowledge of the subject matter.

Slavin (2003) stressed that quality teachers need to know their subject matter, how to motivate children, how to use class time effectively, and how to respond to individual differences. Quality teachers know their subject, and possess the verbal ability to transfer their knowledge to their students (Sadker \& Sadker, 2003; cited; Okpala and Ellis ,2005).

In Turkey, teacher candidates selected by are placed on education faculties by student selection and placement center (ÖSYM). In this selection process, while candidate's test scores are taking into account candidate's personal characteristics and suitability for teaching profession are neglected.

\section{PURPOSE}

In this study a teacher candidate's susceptibility to the teaching profession and whether each candidate would have teacher competencies and skills at the end of the teacher training program were investigated according to the instructors. Despite having responsibilities for educating candidates instructors cannot participate the teacher candidate's selection process. Thus, instructors' views about teacher candidates' teacher characteristic and competences were consulted.

\section{METHOD}

The research is a descriptive study based on screening model. Data were collected through structured interview form which used in qualitative research. For this purpose, 20 instructor specialized in the field of teacher training at two state universities' education faculties were interviewed regarding the suitability of teacher candidates to the teaching profession. Instructors were coded as coded Ö1.....Ö20 and their views were presented according to these codes.

The following questions were asked to the instructors:

1. Do you think teacher candidates educated in education faculties have necessary qualifications and competencies related to teaching profession? Why?

2. Can teacher qualifications be created during 4 years of education program? Why?

3. Does any case that you cannot find solutions?

4. If you involved in the teacher candidates selection process, what features would you like to see in candidates?

\footnotetext{
1 Assoc. Prof., Akdeniz University, Faculty of Education, aysenur.canbulat@gmail.com
} 
Responses of instructors were coded for the purpose of the research. While creating categories code similarities, differences and relationships were considered and each category's repetition frequency were found and shown in table.

\section{FINDINGS}

1. According to the instructors, teacher candidates who interest the teaching profession and have sense of responsibility are more successful.

2. Teacher candidates selection process and the appointment process are not eligible for teaching profession understandings because not to allow to recognize the individual characteristics of the teacher candidates.

3. Regardless of the quality of education given to the teacher candidates, teaching profession can be imparted by the personal characteristics of the teacher candidates.

\section{RECOMMENDATIONS}

1. Teacher candidates should be selected by an ability tests included vocational interests, aspirations and profession skills besides the examinations performed by SSPC (OSYM). Thus, labor, time and capital loss should be reduced.

2. Teacher candidates should be selected from applicants who have competencies related to the children's developmental characteristics and age. For example, if a candidate wants to be a classroom teacher, he/she should have susceptibility to music and motor skills because of their students are game age children.

3. Scientists who are the education specialists should work about how teacher candidate selection application should be. 